\title{
Road surface quality as the basis of safe operation of transport systems
}

\author{
Pavel Grekhov ${ }^{1, *}$, Sergey Levashov ${ }^{2}$, Vladimir Shkrabak $^{3}$, and Roman Shkrabak $^{3}$ \\ ${ }^{1}$ Kurgan State Agricultural Academy by T.S. Maltsev, 641000 Kurgan, Russia \\ ${ }^{2}$ Kurgan State University, 641000 Kurgan, Russia \\ ${ }^{3}$ Saint-Petersburg State Agrarian University, 196661 Saint-Petersburg, Pushkin, Russia
}

\begin{abstract}
The safe functioning of the transport system mainly depends on the quality of road surfaces. Therefore, improvement of the physical and mechanical characteristics of roads will ensure the effective protection of health and safety of people engaged in this field. Consequently, modification of the physical and mechanical characteristics of road surfaces will ensure safety in the field of transport systems. Bitumen-salt mass was used as a modifier of the road bitumen emulsions and such a mass was obtained by means of destructing the chemical weapons of the organophosphorus class of compounds since they have an effect of surfaceactive substances. Studying of the modified road surface parameters was carried out according to the dispersion parameters and using the method of mathematical design of the experiment. As a result, the positive effect of the bitumen-salt mass on the dispersion distribution of the bitumen phase in the bitumen emulsion was determined. The proposed method of modification of the bitumen emulsions allowed us to improve the operational parameters of the road surfaces, and thus the safety of road transport systems as a whole.
\end{abstract}

\section{Introduction}

During the Cold War, large quantities of chemical weapons containing the organophosphorus class of toxic substances (sarin, soman, VX-gases) as the main component were stored in the Soviet Union. After Russia signed the "Convention on the Prohibition of the Development, Production, Stockpiling and Use of the Chemical Weapons and on their Destruction" it was decided to destroy the chemical weapons. Warehousing and storage was arranged at the sites of destruction of chemical weapons. Various options for further utilization of wastes obtained after such destruction were considered, and one of them was using in the road construction, since roads and quality of road surfaces are the most important elements ensuring the safety and reliability of the transport system in Russia.

In January 1993, the question of how to handle 40,000 tons of toxic substances arose. When destructing the arsenal of chemical weapons stored at several sites and having different chemical bases, it was required to determine the mode of decomposition. After the

\footnotetext{
${ }^{*}$ Corresponding author: grehov-pgs@yandex.ru
} 
announcement of competition, the method for destructing the Chemical Weapons of the organophosphorus class of compounds proposed by the State Research Institute of Organic Chemistry and Technology (GosNIIOKhT) (Moscow) was selected, since this class of compounds is contained in the great bulk of all the Chemical Weapons of approximately 32,200 t. [1-3]. This method provides for a two-stage technology involving the initial neutralization of toxic substances such as sarin, soman, VX-gases and obtaining of a reaction mass which is bitumenized at the second stage (mixed with petroleum bitumen). As a result, the bitumen-salt mass of the third hazard category is obtained [4-6]. It should be noted that the amount of the bitumen-salt mass increases compared to the initial amount of toxic substances by 3.5 times. Thus, significant volumes of the bitumen-salt mass may and should be used for industrial purposes.

Due to the significant content of petroleum bitumen in the bitumen-salt mass, it is possible to use these wastes for the production of waterproofing materials (for coating and covering) and in road construction [9]. Analysis of the reaction mass components showed that it can have an effect of surface-active substances [7, 8]. Introduction of surface-active substances into the composition of structural elements of road surfaces will not only improve the mechanical characteristics, but also significantly reduce a number of road accidents. The latter circumstance will ensure an improvement of safety of drivers on the roads, as well as all related infrastructure of road transport systems. This is particularly significant for the roads in rural areas, namely, for the agricultural industry complex, where the machinery of large mass and carrying capacity is used. It also should be noted that these roads have periods of intensive exploitation, such as sowing season, harvesting and transportation of crops.

For the purpose of ensuring high strength and performance of road surfaces, an optimal ratio of various components of the system under consideration is required. One of the main factors is interaction of the bitumen binder with the inert components of the dispersion system of road surfaces $[11,12]$. A high degree of adhesion and spreading of bitumen over the gravel and sand is possible only with the use of bitumen emulsions (BE) [7, 10]. The efficiency of the bitumen emulsion is determined by the efficiency of emulsifiers, namely, surface-active substances, introduced into its composition. Therefore, when introducing the bitumen emulsion and petroleum bitumen into the composition the bitumen-salt mass can ensure an improvement of physical and mechanical properties of asphalt concrete [9]. In view of the fact that the bitumen emulsion is a multiphase system, the surface-active substances will influence the dispersion of the dimensional parameters of the bitumen phase, and, consequently, the resistance to delamination and spreading capacity. Similar experiments were carried out with the use of conventional Surface-Active Substances but experiment with the use of the bitumen-salt mass was carried out for the first time. Determination of the dispersion parameters of the bitumen emulsion was carried out according to the compositions using the experiment design theory and preparing a simplex design as per the "composition-property" scheme according to Table 1 below. Whereupon, a mathematical model was created with verification by Kohren and Fisher criteria. Bitumen of BND 60/90 grade was used as one of the Bitumen Emulsion phases.

\section{Study method}

For determining the dispersion parameters, the SHIMADZU SALD-7101 unit was used. This unit is suitable for determining the dimensional and quantity characteristics of the bitumen phase in the bitumen emulsion. Analysis of the differential parameters of the bitumen emulsion compositions being studied was evaluated taking into account predefined parameters of spreading capacity, since in compliance with the normative documentation the mineral components should be covered with a bitumen component by at least two-thirds 
of the surface area of the mineral component. In addition, the disperse range of dimensional parameters of the bitumen phase increases thus leading to a decrease in the contacting number of bitumen micro-droplets. An increase in the dimensional parameters range (minimum dimensions) leads to an increase in the surface area of the phase boundaries, which activates the processes of chemical dispersion and micellar catalysis.

Table 1. Disperse system stability index depending on the amount of introduced Bitumen-salt mass.

\begin{tabular}{|c|c|c|c|c|c|c|c|c|c|c|}
\hline \multirow{2}{*}{$\begin{array}{l}\text { Component } \\
\text { description and } \\
\text { time index of } \\
\text { the disperse } \\
\text { system }\end{array}$} & \multicolumn{10}{|c|}{ Numbering and ratios of components of experimental compositions } \\
\hline & 1 & 2 & 3 & 4 & 5 & 6 & 7 & 8 & 9 & 10 \\
\hline Bitumen, $\%$ & 60 & 50 & 50 & 53.3 & 56.6 & 56.6 & 53.3 & 50 & 50 & 53.3 \\
\hline Water, \% & 40 & 50 & 40 & 40 & 40 & 43.3 & 46.6 & 46.6 & 43.3 & 43.3 \\
\hline $\begin{array}{l}\text { Modifying } \\
\text { additive } \\
\text { (Bitumen-salt } \\
\text { mass), \% }\end{array}$ & 0 & 0 & 10 & 6.6 & 3.3 & 0 & 0 & 3.3 & 6.6 & 3.3 \\
\hline $\begin{array}{c}\text { Hydrochlori } \\
\text { c acid, HCL, } \\
\%\end{array}$ & \multicolumn{10}{|c|}{0.20} \\
\hline $\begin{array}{c}\text { Emulsifier } \\
\text { Redicote EM44, } \\
\%\end{array}$ & \multicolumn{10}{|c|}{1.5} \\
\hline $\begin{array}{l}\text { Time to the } \\
\text { moment of } \\
\text { delamination, } \mathrm{h}\end{array}$ & 409 & 527 & 0.15 & 333 & 501 & 379 & 547 & 145 & 0.3 & 337 \\
\hline
\end{tabular}

\section{Results}

While comparing the dimensional and quantity parameters of the bitumen phase with or without bitumen-salt mass in the bitumen emulsion composition, one may note the significant differences. Thus, in compositions without bitumen-salt mass there are significant changes in quantitative parameters (\%) of some sizes of micro-droplets of the bitumen emulsion of $8-9 \mu$ (Fig. 1) and 8-10 $\mu$ (Fig. 2) respectively. The presence of bitumen-salt mass in such compositions leads to changes in the distribution of dimensional and percentage parameters of the bitumen phase distribution. It proves that the reaction mass exhibits the properties of the surface-active substances expressed in the appearance of smaller micro-droplets of bitumen in the emulsion. Thus, in the composition No. 5 (Fig. 3) the presence of micro-droplets with size of less than $1 \mu$ and more uniform distribution of particles within the range from $3-15 \mu$ are observed. In composition No. 10 (Fig. 4) including bitumen-salt mass the appearance of micro-droplets with size starting from $0.8 \mu$ is observed as opposed to the compositions without bitumen-salt mass (Figs. 1 and 2). 


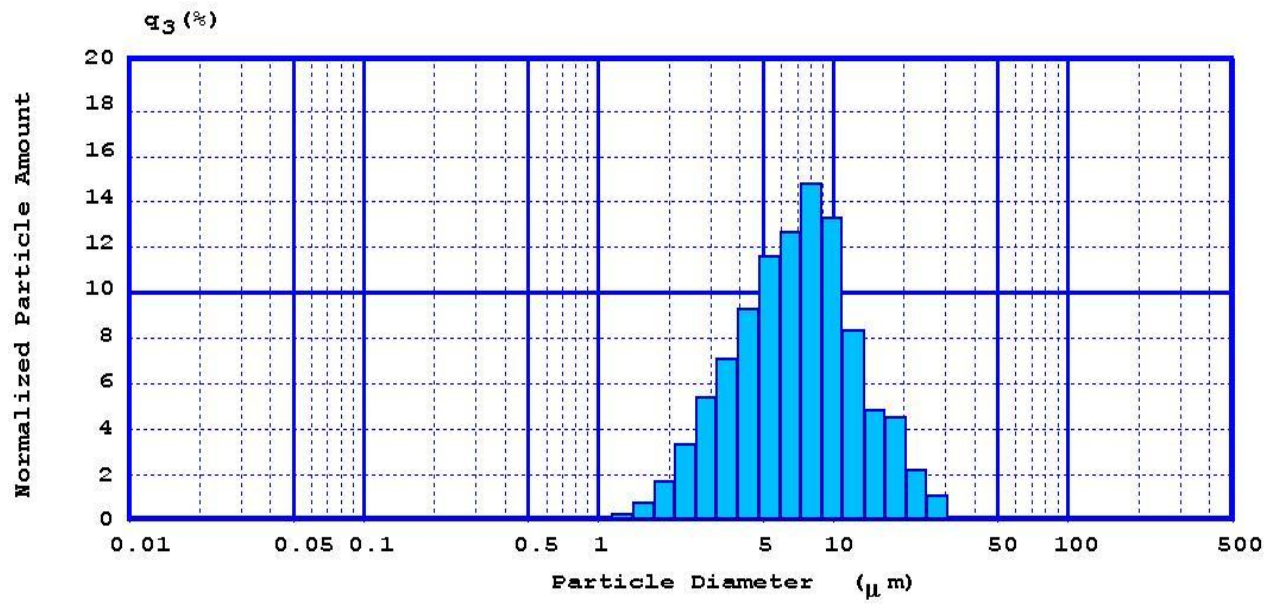

Fig. 1. Dispersion parameters of the bitumen phase of composition No. 6 (Table 1).

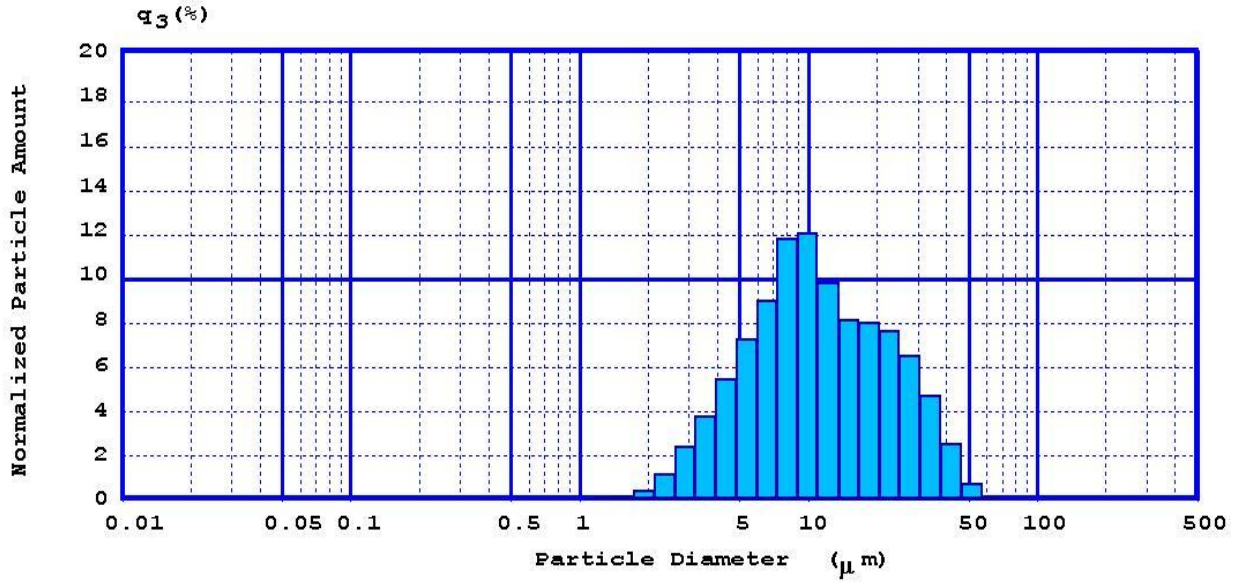

Fig. 2. Dispersion parameters of the bitumen phase of composition No. 7 (Table 1).

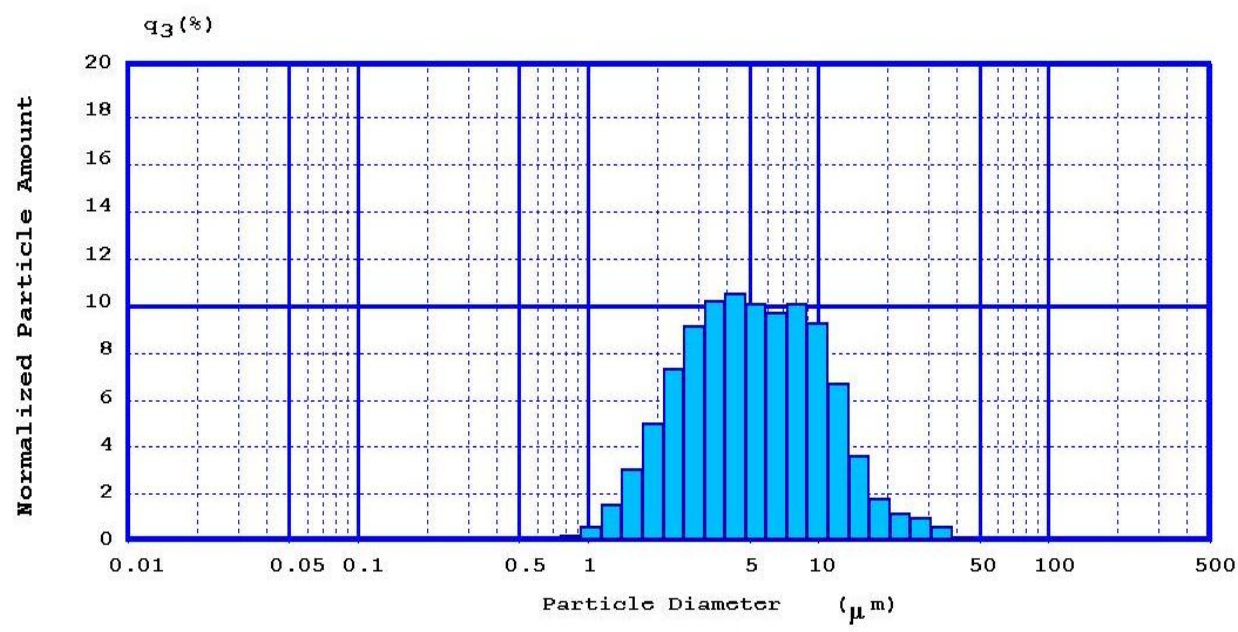

Fig. 3. Dispersion parameters of the bitumen phase of composition No. 5 (Table 1). 


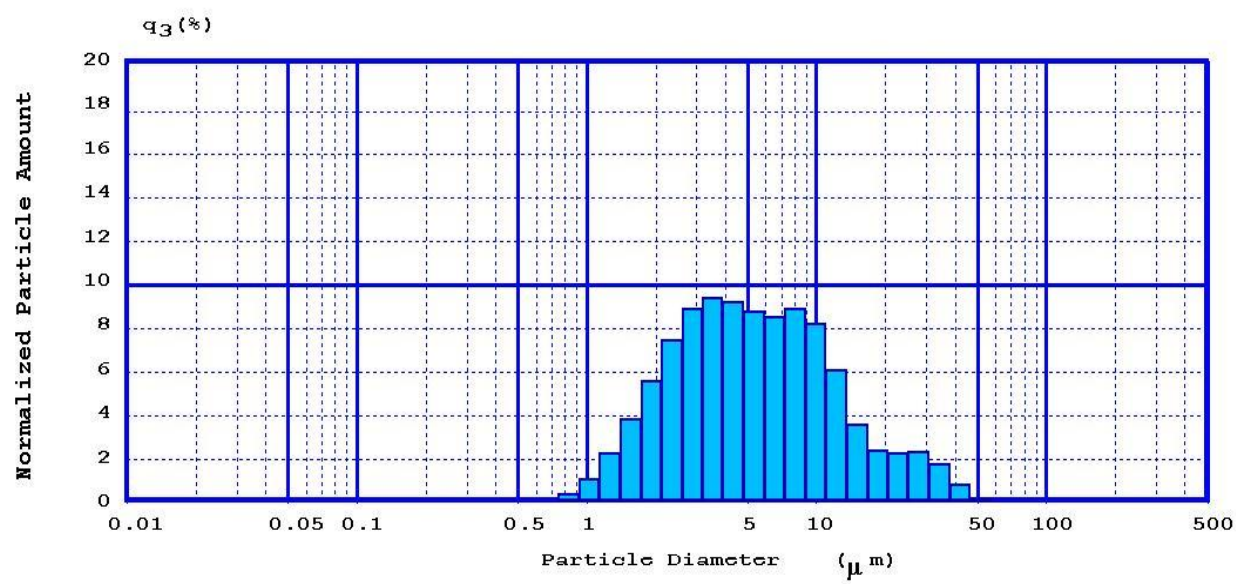

Fig. 4. Dispersion parameters of the bitumen phase of composition No. 10 (Table 1).

Since the spreading capacity and delaminatability of the bitumen emulsion relate to the thixotropic characteristics, and the bitumen phase in the oil-in-water system has the shape of a sphere or something close to it, consideration of the effect of internal interactions is impossible without application of the closest packing theory. According to this theory, the maximum filling volume of a single cell with identical spheres is possible only by $75.05 \%$, and in this case, there will be voids, one octahedral and two tetrahedral [7]. However, the bitumen emulsion has spheres of bitumen phase of different diameters, which will cause a change in the contacting number in the dispersion system. Ideally, the contacting number is maximal, but if the dispersion of spheres by size and quantity does not correspond to the closest packing theory, then the contacting number decreases. Therefore, for increasing the time before delamination it is necessary to strive for decreasing the contacting number of spheres of the bitumen phase in the bitumen emulsion, since the surface-active substances are displaced at the contact points of the bitumen spheres to other surfaces thus accelerating the processes of coalescence.

When considering the ratio of components in the bitumen emulsion as indicated in Table 1, it can be seen that the amount of bitumen phase does not exceed $60 \%$, therefore, the micro-droplets do not contact each other and are completely washed by the liquid (water) phase. Particularly it is possible to distinguish the compositions No. 3 and No. 9, where the stability indicators related to time differ (by several orders of magnitude) from those of other compositions. These compositions are characterized by a high content of the bitumen-salt mass in the bitumen phase; therefore, the concentration of the reaction mass on the surface of bitumen micro-droplets will be maximal. The amount of bitumen is minimal for the interval under consideration, which entails a decrease in the surface area and increase in the concentration of the reaction mass of the Bitumen-salt mass at the interphase boundary. Then a rapid reduction of the bitumen emulsion stability time is explained by the formation of micelles of surface-active substances at the inter-phase boundary between the "bitumen-water" phases and the subsequent occurrence of micellar catalysis [8].

Compatibility of Redicote EM44 emulsifier and bitumen-salt mass in bitumen emulsions is proved, which will improve the quality of the joint operation of different layers of road surface. The amount of the bitumen-salt mass in the bitumen phase should not exceed $6.6 \%$ - this will ensure the optimal formation of the dispersed structure of the bitumen emulsion. When performing further selection of the disperse system compositions, 
the amount of hydrochloric acid and emulsifier may be significantly reduced, which will positively affect the economic indicators.

\section{Conclusion}

Thus, the introduction of the bitumen-salt mass into the composition of the bitumen emulsion will allow us to modify the dispersion parameters, which will ensure high performance characteristics of the road surfaces. It will ensure improvement of transport systems safety. The obtained results may be applied for industrial complexes producing elements of road surface. Further studies are relevant to insulating and binding materials (reinforcement of roadsides and road slopes).

\section{References}

1. V.M. Kolodkina, I.I. Manilo, Shhuchanskij arsenal himicheskogo oruzhija. Predvaritel'nyj prognoz ugrozy naseleniju [Shhuchanskij chemical weapon arsenal. Preliminary forecast of threat to civilians] (IPP «DAMMI» Publ., 1997). (in Russian)

2. N.I. Kalinina, Himija ili zhizn'? Vybiraem zhizn' [Chemistry or life? We choose life] (Kurgan, 1997). (in Russian)

3. Y.I. Livanov, I.I. Manilo, Zadacha optimal'nogo upravlenija tehnologicheskoj sistemoj objekta po unichtozheniju himicheskogo oruzhija [Task of optimal control of technological system of chemistry weapon destruction facility] (NCSP "Ekonomika i Reformy" Publ., Kurgan, 1998). (in Russian)

4. U.I. Musijchuk, Medicinskie problemy unichtozhenija himicheskogo oruzhija [Medical issues of chemical weapon destruction] (Kurgan, 1997). (in Russian)

5. V.A. Petrunin, V.V. Sheluchenko, V.V. Demidjuk, Problemy Rossii v realizacii konvencii po zapreshheniju himicheskogo oruzhija: sostojanie i perspektivy $k$ koncu 2000 goda [Problems of Russia in implementation of the Convention on prohibition of chemical weapons: state and prospects by the end of 2000] (Agentstvo Rakurs Publ., Moscow, 2001). (in Russian)

6. V.A. Petrunin, V.V. Sheluchenko, V.V. Demidjuk, Federal'nye i regional'nye problemy unichtozhenija himicheskogo oruzhija. Informacionnyj sbornik [Federal and regional problems of chemical weapons destruction], Vol. 1 (VNIITI Publ., Moscow, 1999). (in Russian)

7. P.I. Grekhov, V.S. Shkrabak, Bulletin of Saint-Petersburg State Agrarian University, 40 (2015). (in Russian)

8. M.I. Kuchma, Poverhnostno-aktivnye veshhestva v dorozhnom stroitel'stve [Surfaceactive substances in road construction] (Transport Publ., Moscow, 1980). (in Russian).

9. P.I. Grekhov, V.S. Shkrabak, RU Patent 2579128 (2014). (in Russian)

10. P.I. Grekhov, V.S. Shkrabak, RU Patent Application No. 2017106846 (2017). (in Russian)

11. A.I. Kitajgorodskij, Vvedenie v fiziku [Introduction to physics] (Nauka Publ., Moscow, 1973). (in Russian)

12. I.V. Berezin, K. Martinek, A.K. Jacimirskij, Russian Chemical Reviews, 42 (10), (1973). (in Russian) 